\title{
SPECTROCHEMICAL COBALT, MOI.YBDENUM AND COPPER DETERMINATIONS IN PLANTS
}

\author{
by \\ J. SMrT AND J. A. SMT\% \\ I'hysecal Laboratory of the Uneversity, Utrecht (Netherlasts)
}

1. INrkonucernox

Spectrochemical analysis is one of the few possible methods for determining trace elements in plant samples, and in other biological material, soils and soil cxtracts, etc. In this paper the elements considered are restricted to $\mathrm{Co}$, Mo and $\mathrm{Cu}$, which elements are prescent in oven dry plant material for about $5 \cdot 10^{-5}, 2 \cdot 10^{-4}$ and $10^{-3} \%$ respectively. The analysis method dealt with may also be used for the other enumerated kinds of samples and as a general method regarding elements and samples. It has been extensively treated elsewhere ${ }^{1}$. In many aspects the pioncering work of MrTCinill c.s. was followed 2, 12, 13, 14. Additional and differing aspects will be treated below.

II. H.IGIT SOURCE, OPTICS AND METIOD OF INTENSITY MEASUREMENT

\section{Light sourct}

After a suitable pretreatment (sec 111) the content of the concerned elements in the sample amounts to about $10^{-2} \%$ (except for a case touched in III. 4).

It has been checked that only the carbon arc cathode layer ${ }^{3,4}$ and the socalled "high voltage a.c. arc" " B. " - which essentially is a cathode layer arc over its whole length - possess a sufficient sensitivity for an accurate trace element determination in the content range concerned. This sufficient sensitivity arises from the favourable line to background ratio in the spectrum of the cathode layer light. In the cxperiments for the carbon arc cathode layer the sample was introduced in the hollow, lower electrode as a dry powder; for the high voltage arc the sample was present as a thin film of salts after evaporation of a solution on the top of the flat lower electrode.

* It hatd better be called "small clectrode distance arc".

lieforences p. $2 \$ 2$. 
As the result of the orientation the carison arc cathode layer has been preferred for its simpler design, while it is also less dangerous in handling. For cletails of the arc arrangement literature ${ }^{1,2}$ may be consulted.

\section{Spectral apparatus}

As a spectral apparatus a Hilger Large Quartz spectrograph was applied. Because of its high resolving power the favourable line to background ratio of the carbon arc cathode layer is well retained. A high resolving power is desirable because many iron spectral lines are present, coming from some percents of iron in the pretreated sample (see III).

A prism spectrograph is more preferable than a grating spectrograph for its great luminosity. In a provisional experiment the estimative luminosity ratio of a large prism and a $2 \mathrm{~m}$ grating spectrograph appeared to be ca. 50 (the surfaces of the side wall of the prism and of the grating were so and 20 scpuare cim respectively).

A quantitative analysis has been carried out of the influence of temperature on the adjustment of a large size Littrow type spectrograph. It showed that the only significant change in adjustment is caused by two effects in the quartz prism. Firstly, the refractive index is dependent on temperature and, secondly, the refracting angle decreases at increasing temperature because of the anisotropy of quart\%. These cffects result in a shift of the spectral line of $c a$. $0.005 \mathrm{~cm} /{ }^{\circ} \mathrm{C}$. The theoretical line halfwidth on the plate amounts to $\mathrm{ca} .0 .003 \mathrm{~cm}$. Comparison of both values shows that the effect is troublesome for photographic work with very long exposures and for series of photoclectric incasurements, unless the temperaturc is kept constint.

\section{Oplics}

To separate the cathode-layer light from the light emitted by the rest of the discharge the arc was larger imaged on a diaphragm. To have a short light path we have erected that diaphragm inside the spectrograph. In this way the required homogeneous slit illumination (sec II. 4) is obtained simultaneously.

It must be noted that a homogencous slit illumination does not always give the wanted homogeneous spectral line on the plate*. The homogeneous line is only obtained when the light of the separated layer entering the slit is nowhere in the spectrograph prevented in reaching the plate**. For this purpose it was thought preferable to erect in the used Littrow type spectrograph the previously:

- A spectral line is called homogeneous when the (maximum) photometric demity of the photographed line is independent of the place in the Iongitudinal ditectun of the line.

** An inevitable loss in light as a consequence of reflection at the quart\% surfaces i; left out of account.

References $p .2 \delta 2$. 


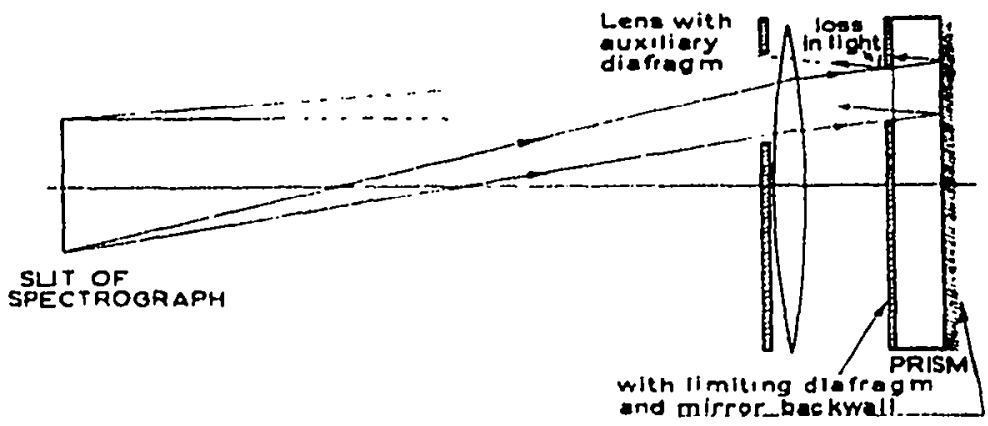

mentioned diaphragm just before the prism side wall and not before the collimator lens. An auxiliary diaphragm may be present on the lens to avoid unwanted reflection light; its opening, however, must be so large that it does not limit the light path.

lig. I. Showing an exagyeration of the incritable (minimum) loss in light when the cliaphragm is erceted just in front of the prism.

When all mentiuned points are observed a small ineritable inhomogeneity remains in the line on the plate. It arises from the fact that in a Littrow type spectrograph the light passes in its forward and backward way the diaphragm limiting the light path. The diaphragm cannot coincide with the mirror behind the prism and therefore prevents a part of the light, reflected by the mirror, from reaching the plate, as it is illustrated in Fig. I.

The deviation from homogeneity can be calculated and measured. When the height of the opening in the diaphragm is $1 \mathrm{~cm}$, the deviation amounts to about $3 \%$ when this limiting diaphragm is erected in front of the prism. The deviation increases when the mentioncd cliaphrigm is more removed from the mirror back wall of the prism, c.g. it amounts to about $x 0 \%$ when the diaphragm is erected in front of the collimator Jens.

It is desiralole to have the homogeneity of the spectral line checked at intervals, since it maly be disturbed by small disarrangements in the optics and the slit of the spectrograiph.

When a spectral region of larifer extent (c.g. I000 A) is obscrved, an achromatic lens is required for the focussing of the source on the diaphragm. This image must be very sharp, otherwise errors far beyond the mean crror of the method (see IV. 3) arc introduced, at any rate in the case of a very inhomogeneous light source as a cathode layer*. It is not necessary to place this imaging lens just in front of the spectrograph slit. This is even undesirable when the lens shows small irregularities, as a quartz-fluorite achromatic lens often does.

\section{Plate calibration}

It was convenient to start the rescarch with the photographic plate as a detector. A photoelectric measurement method is in preparation now ${ }^{\overrightarrow{7}}$.

In agreement with MrTcilell c.s." the blackening curve separation method 8,0 has been chosen for the cletermination of relative intensities in the spectrum.

* Quantitative clatia page 59 of the first reference.

References p. 252 . 
This method was preferred in our case to the methed of the precalibrated iron lines ${ }^{10}$ and the line width method ${ }^{11}$. Other methods were not to be considered.

The choice of the method of the blackening curve separation implies the requirement of a homogeneous illumination of the slit, in front of which a rotating step sector has been placed.

In the plate choice a great number of considerations play their part (c.g. desirable three minutes exposure time given by complete evaporation of the sample, luminosity of spectrograph after diaphragmation, trace element content range to be considered, etc.). It was a lucky chance that all the requirements could be met by application of a usual plate (e.g. Gevaert Normal or Ilford Special Rapid).

\section{CHEMICAI. PRETREATMENT}

\section{Scopes of pretreatment}

For biological samples it is necessary in most cases to apply a pretreatinent to obtain the material in a suitable state for spectrography (to avoid foaming and spluttering at arc striking etc.). At the same time concentration of the trace elements and standardisation of the sample may be reached.

\section{Earlier pretrentment for Co- and Mo-ditcrminations}

At first a pretreatment was applied as it is described in literature $2,12,13$. In short this pretreatment consists of: dry ashing of the sample (mostly ro grams) for I2 hours at $450^{\circ} \mathrm{C}, c . g$. in a muffle furnace - cxclusion of silica inclusions by soda melt - dissolving the melt in dilute acid - precipitation of trace clements, iron and aluminium (added as a carrier) by supply of chemicals, e.g. oxyquinoline - filtration of the precipitate, followed by dry ashing. The sample consists then of $\mathrm{Al}_{2} \mathrm{O}_{3}, \mathrm{Fe}_{2} \mathrm{O}_{3}$ (some percents) and trace elements (mostly about $0.01 \%$ ).

In this way, however, we could not succeed in obtaining spectrochemical analysis results, agreeing sufficiently with colorimetric ones for Co and Mo. In the mean the spectrochemical results were about $30 \%$ lower.

\section{Application of roct ashing}

This discrepancy disappeared (sec IV, 4) when the first dry ashing and the soda melt were substituted by wet ashing with $\mathrm{H}_{2} \mathrm{SO}_{4}$, $\mathrm{HNO}_{3}$, and later on with $\mathrm{HClO}_{4}$. To avoid absorptions at $\mathrm{CaSO}_{4}$, etc. the diluted destruction fluid is boiled for half an hour, whereupon the silica and the occasional calcium sulphate are filtered. The filter is washed two times with hot very diluted sulphuric acid. In the dilute acid filtrate the precipitate is obtained as described above.

The time required for a pretreatment is about the same in both cases (III. 2 and 3).

References p. 282 . 


\section{Pretreatment for Cu-determinations.}

When one is only interested in the copper content of the sample a dry ashing suffices for reason of the relatively high content in the original sample. After addition of $\mathrm{K}_{2} \mathrm{SO}_{4}$ as a spectroscopic buffer the sample is ready for spectrography 1,2,14.

The simultancous determination of $\mathrm{Cu}$ in the presence of $\mathrm{Co}$, Mo, etc. is in preparation.

\section{Internal stendard}

\section{MIEASUREMHNS}

The large fluctuations in the intensity of spectral lines in an arc require application of an internal standard for an accurate deduction of contents in the sample from measured intensitics. In oricntating experiments concerning Co- and Mo-determinations the results were as follows. When no internal standard is applied and the required contents are cleduced from the rreasured densities of the photographed spectral lines, the accidental error is five times larger than in the case of the application of an internal standard method as also described in this paper (cf.IV. 3); when the contents are deduced from line/background ratios the accidental error is a factor two or threc larger.

As analysis lines we used $\mathrm{Co} 3453.5$, Mo 3170.35 and $\mathrm{Cu} 3274.0 \mathrm{~A}$. According to the literature ${ }^{2}$ we first applied as reference lines $\mathrm{Fc} 3452.0$, Fe 3 r97.0 and Ag 3280.7 A, resp.

Ag 3280.7 is a perfect stanclarcl line. The difference in upper level of both elements amounts to $0 . \mathrm{I} \mathrm{eV}\left(\mathrm{Cu}_{3.7}, \mathrm{Ag} 3.8 \mathrm{cV}\right)$. This means that at an arc temperature of about $4000^{\circ} \mathrm{K}$ a temperature variation of $500^{\circ}$ causes a variation of only $3 \frac{1}{2} \%$ in the relative intensity of these lines*.

Both the iron lines possess an upper level of about $6 \mathrm{cV}$, while that of the Co- and Mo-line is about $4 \mathrm{cV}$. Now at $4000^{\circ} \mathrm{K}$ a variation of $100^{\circ} \mathrm{K}$ gives a variation of $15 \%$ in relative intensities. A wavelength identification of about So iron lines on our plates in the region between 3500 and $3100 \mathrm{~A}$ showed that only one suitable iron line with an upper level of $4 \mathrm{cV}$ is present, namely $3 \mathrm{rgr}^{\mathrm{r}} 6 \mathbf{\mathrm { A }} \mathrm{A}$. It may be used in combination with Mo 3170.35 .

\section{Proportionality betreen spectral relative intensity and content ratio in the sample}

In a standard graph measured relative intensitics arc plotted against trace element content of the sample at fixed amounts of $F_{c}$ in the sample. The varying Fe-content of the analysis samples - up to now colorimetrically determined ${ }^{15}$ may be taken in account $e . g$. with the help of an iron correction curve ${ }^{1,2}$.

* Cf.e.g. form. II. 3 in the first reference. As a consequence a stringent equality between standard and analy'sis sample is not required at all in such a case; cf. loc.cıl. pages $I I S$ and $I 25$.

References $p .282$. 
The procedure of relative intensity measurements includes important corrections for spectral background ${ }^{1,2}$ and spectral inhomogeneity (cf. II.3) ${ }^{1}$.

The amount of the element in question (e.g. $\mathrm{Cu}, \mathrm{Co}$ ), originating from electrodes and chemicals, must be often taken into account. These so-called blank amounts and the correlated relative intensities may be determined with the help of a graph in linear plotting, as it is illustrated in Fig. 2.

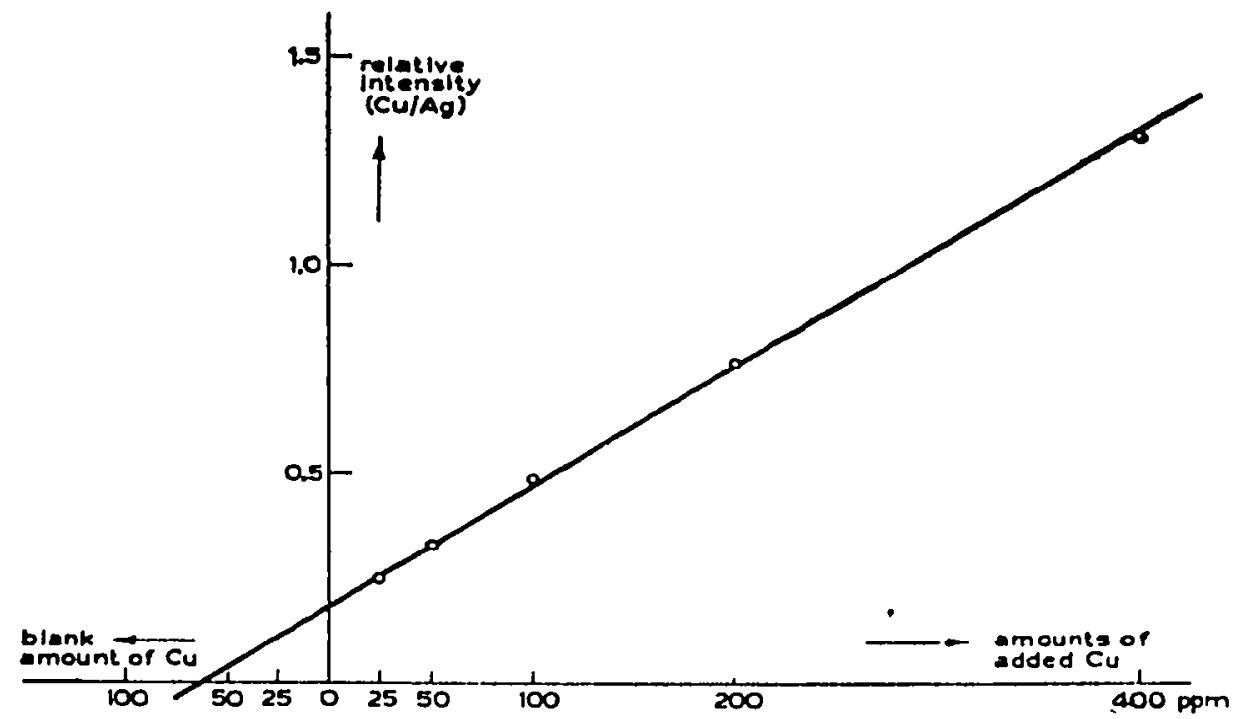

Fig 2

lig. 2. I.inear plotting of relative intensitien against content to determine a blank amount of copper.

After application of the required corrections our standard graphs in double logarithmic plotting had approximatively a $45^{\circ}$ slope. This means that in the content ranges consiclered (Co, Mo: 30-rooo ppm; $\mathrm{Cu}: 25-400 \mathrm{ppm}$; Fe some percents; $\mathrm{Ag}$ : I00-400 $\mathrm{ppm}$ ) there is proportionality between relative intensities in the arc and content ratio in the sample.

"This conclusion was confirmed by a "dilution test". To a sample consisting of $\mathrm{Al}_{2} \mathrm{O}_{3}, 5 \%, \mathrm{Fe}_{2} \mathrm{O}_{3}, 500 \mathrm{ppm} \mathrm{Co}$ and $\mathrm{Mo} \mathrm{Al}_{2} \mathrm{O}_{3}$ have been added, the first time half the weight of the sample, the second time the full weight. In that way the trace clement standard ratio had not been changed and indeed the measured relative intensities in spectra of the original and diluted samples agreed within the experimental margin*.

* Quantitative results: pages 92 and 102111 first refarence.

References $p .282$. 


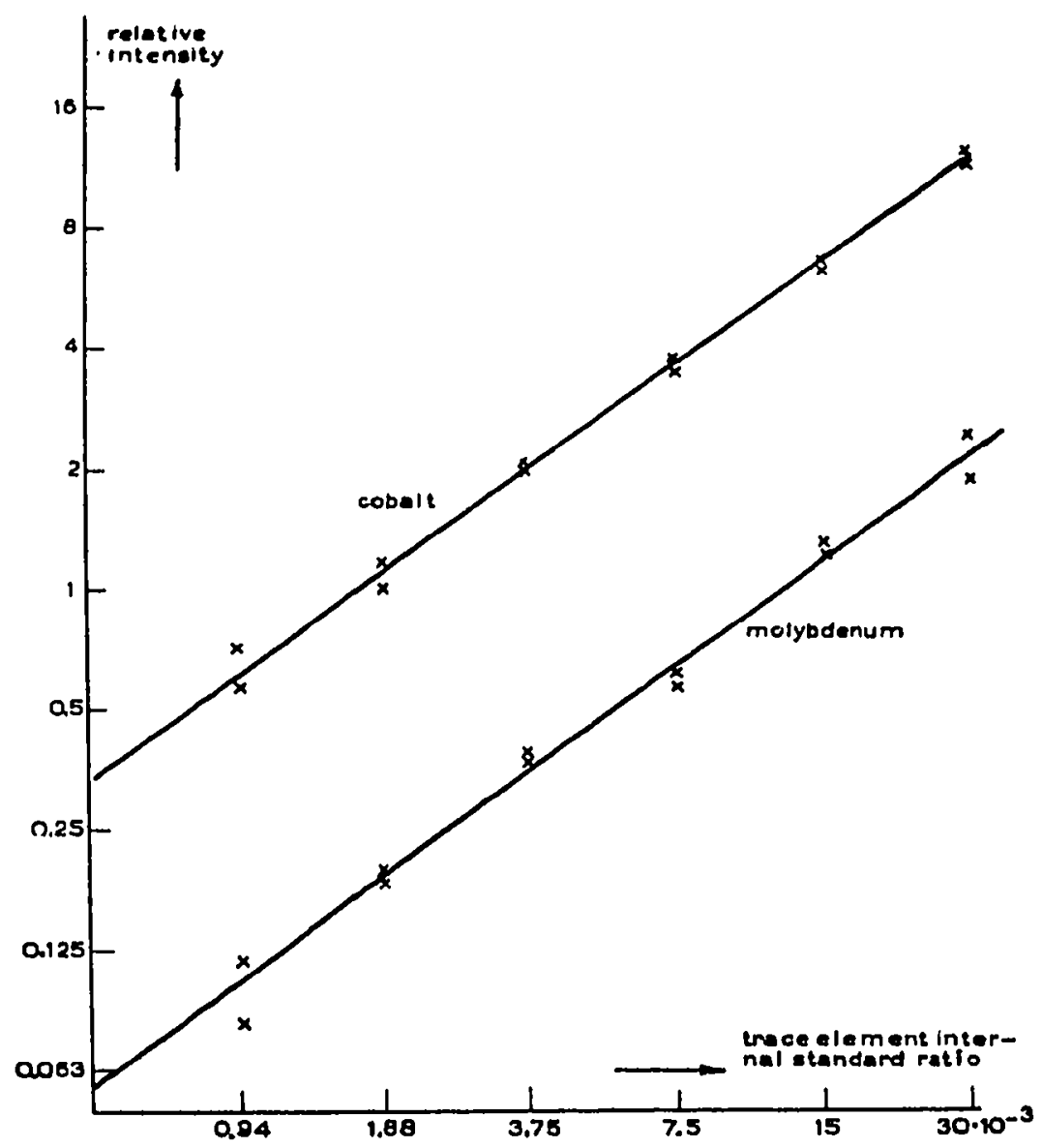

Fig. 3. Calibration curve by the help of which relative intensities can be converted into contents in the sample without application of an iron correction curve. On the abscissa the content ratio $\mathrm{Co} / \mathrm{Fc}$ or $\mathrm{Mo} / \mathrm{Fe}$ has been plotted; on the orclinate the

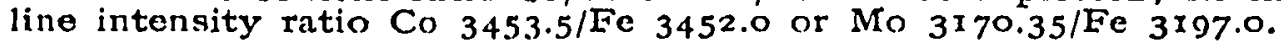

Consequently for calibration one graph suffices, in which the intensity ratio is plotted against the content ratio of trace and reference element; see Fig. 3 . An iron correction curve is superfluous.

\section{Spcctrographic and spectrochemical reproducibility}

When we deal with "spectrography" only the physical part of the determination is meant, starting with electrode filling up to the determination of relative intensitics. The term "spectrochemistry" is concerned with the complete analysis starting with plant ashing up to content determination, deduced from measured relative intensities via calibration.

References p. 282 . 
The spectrographic accuracy* of the relative intensity measurement in a single spectrum for, the pairs of lines mentioned sub IV. I appeared to be $8 \%$. This result is based on about roo measurements.

The spectrochemical reproducibility* amounts to Ic $\%$. It is a result of amply Ioo determinations.

These results are satisfactory for the analysis in question. For further dutails and a discussion of crrors the first reference may be consulted.

\section{Comparison of colorimetric and spcctrochemical results}

In a first experiment $\mathrm{Cu}$ has been determined in $5^{\circ}$ grass samples in colorimetric and spectrochemical way. The mean of both series of determinations in dry material was $12.8 \mathrm{pPm}$ (12.77) and 12.8 (12.84), resp. It may be concluded that there are no systematical deviations between both methods. The accidental deviations in the couples of results, obtained in the analysis of the same samples in both ways, were in agreement with the accidental error of $10 \%$ for each melhod separately.

After several series of orientating experiments also for Co and Mo comparable results have been obtained with a smaller number of samples. (ro samples; Co: $0.70 \mathrm{ppm}$ spectrochemical, $0.6 \mathrm{I}$ colorimetric; Mo: I.8 and I.75, resp.).

The check will be continued for other clements, c.g. Zn.

\section{ACKNOWLEDGEMENTS}

The first author wishes to thank the National Council for Agricultural 12escarch (T.N.O.). for their permisision to publish this research in a thesis and in this paper. Gratitude goes also to all the people in the laboratory who contributed to the research with their interest, help and discuissons, especially to Prof. Dr J. M. W. Milat\%, the director of the laboratory.

\section{SUMMARY}

This paper deals with the spectrochemical determination of some trace elements $(\mathrm{Cu}, \mathrm{Mo}$ and $\mathrm{Co}$, especially in plant samples. Data are given about the choice of light source and spectral apparatus, as vell as detailed remarks concerning the optical arrangement.

In the concelltrating pretreatment with precipitating chemicals a wet ashing has been proved to give better results than a dry ashing.

* The standard deviation $D$ is given. Lor a series of spectra belonging to one sample $D$ is calculated according to the well-known formula: $D=\sqrt{\frac{\bar{\Sigma}(x-\bar{x})^{2}}{n-1}}$ ( $x$ and $\bar{x}$ : actual and mean value, $n$ : number of measurements).

References p. 282 . 


\section{RESUME}

Cet article concerne l'analyse spectrochimique de traces de cuivre, molybdène et cobalt, en particulier clans les plantes. On traite du choix de la source lumineuse, de l'appareil spectral et de l'arrangement optique.

in ce qui concernc le traitement préalable de concentration, la minéralisation par voie humide est préférable à celle par voie seche.

\section{ZUSAMMENIASSUNG}

Dieser Artikel behandelt die spektrochemische Bestimmung ciniger Spurenelemente (Cu, Mo und $\mathrm{Co}$ ), besonders in Pflanzen proben. Es werden sowohl Angaben gemacht uber die Wahl der Lichtquelle und des Spektralapparates, als auch eingehende J3emerkungen, die die optische Anordnung betreffen.

Bci cler Vorbchandlung mit Fallungsreagenzien zur Konzentration wurde bewiesen, dass eine Veraschung au nassem Wege bessere Werte ergab als eine Veraschung auf trockenem Wege.

\section{REFERENCES}

1 J. SmIT, thesis Utrecht, 1952.

2 R. L. MitCHELL, The spectrographic andalysis of soils, plants and related materials, Commonwealth Bureau of Soil Science, Harpenden, England, 1948.

s 1R. MANNKoptr AND C. Peters, Z. Phys.. 70 (T931) 444.

4 L. W. SrRock, Spcctrum analysts ievith the carbon arc cathodclayer, London (Hilger). x 936.

- O.S. Dufrendack ANd R. A. Wolfe, Ind. Eng. Chem., Anal. Ed., ro (1938) r6r.

- $T$. M. Hilss, J. S. OWENS AND L. G. REINHANDT, ditto, I1 (1939) 646 .

7 J. M. W. MiLAt\% F. BOEschoteN AND J. A. SMrT, Physica, 88 (1952) 646.

a L. S. ORNSTEIN, iV. J. H. MOLI AND H. C. BURG ER, Objektive Spehtralphotometrie, (pas. 89). Braunschweig. 1932.

- ir. Brecicrot, Spectrochin. Acta, $x$ (x939) 137.

$10 \mathrm{~J}$. Churcilll, Ind. Eng. Chein., Anal. Ed. r6 (1944) 653.

11 V. GIRLACH, F. P. COHEUR AND P. CoIIUU, Bitll, soc. voy. sci. Lidge, 4 (1940) 79.

12 IR. O. Scott AND IR. I. Mxtchele, J. Soc. Chem. Ind., 62 (1943) 4.

10 R. L. Mitcheld AND R. O. Scotr, ditto, 66 (1947) 330.

14 V. C. Farmer, Spechochim. Acta, 4 (1950) 244.

is 1i. O. Scotr, Analyst, 66 (194T) $\times 42$. 